特集「第14回大会」

\title{
原著論文
}

遊びロボットによる子どもの性格傾向の推定に関する研究

\author{
岩崎 安希子*, 下斗米 貴之*, 阿部 香澄**, 中村 友昭**, \\ 長井 隆行**, 大森 隆司* \\ *玉川大学, ** 電気通信大学
}

\section{Estimating Children's Personality Tendencies by a Playing Robot}

\author{
Akiko IWASAKI*, Takayuki SHIMOTOMAI*, Kasumi ABE**, Tomoaki NAKAMURA**, \\ Takayuki NAGAI** and Takashi OMORI*
}

\author{
* Tamagawa University, 6-1-1 Tamagawa-gakuen, Machida, Tokyo 194-8610, Japan \\ ** The University of Electro-Communications, 1-5-1 Chofugaoka, Chofu, Tokyo 182-8585, Japan
}

\begin{abstract}
Various robots had been developed lately, not only for industrial use but for home use too. In our previous study, we had developed a playmate robot system that is designed to play with children. Child personality observation is important during play situations for smooth interaction, in order to sustain the child's interest. Therefore, we considered that the robot system should be able to distinguish children's personality types or tendencies. As a result, the relationship between the child's personality test score and head movement observed during the robot play interaction was found to be significant. This suggests the possibility of an adaptive robot system that plays with children in accordance to each child personality.
\end{abstract}

Keywords : playmate robot, children, personality test

\section{1.はじめに}

近年, 産業用・研究用のみならず生活の中にまでロボット が進出し，我々がロボットに接する機会が増えている。近い 将来，家庭環境で人と暮らすロボットも商品化され，ロボッ トと人とのインタラクションがますます多くなるであろう.

これまで, 子どもと遊ぶロボットに関して多くの研究報告 がある [1-9]. 遊びの実現には環境・状況の認識だけでなく, 相手の心的状態の認識とそれに基づいた行動決定が必要とな る. 特にロボットとの遊び場面における子どもの状態の推定 手法に関しては, 興味度 $[1,2]$ や対人的感覚 [3], 親近感 [4], 没頭度 $[5,6]$ に関する研究報告がある。例えば高橋らは ロボットと子どもの関係性を新奇性と親近性という2つの 視点で評価し，新奇性だけでは子どもがすぐに飽きてしま い適切な関係を築くことができないことを示している $[4]$. 一方で, 対人という意味では自閉症の遊戯療法が目的の口 ボット [10-13] やサービスロボット [12-14]も多く研究され ているが，これらは子どもとのインタラクションを特に目 的としているわけではない.

遊びのインタラクションをするロボットは，遊び相手の情 報を知ることが重要である。先行研究 $[1-3,7]$ でも指摘さ れているように遊びロボットに拈ける一つの目標は, 子ども を飽きさせないことである．飽きさせないために現在の多く のロボットが取っている方策は，声をかけたり次々と新しい 働きかけをして新奇性をもって興味を引く，というものであ る.しかし, 単に新奇な遊びを提示していても, それがその まま子どもの興味の維持につながるとは限らない，現実に
は，ロボットはプログラムに従って動く機械であり，子ども の好みにあった行為で働きかけるシステムの実現には，相手 の好みや性格をロボットが知っている必要がある。ささにそ の好みや性格から適切な働きかけをする必要もある。しか し, 前述の研究はいずれも, 複数の第三者の主観的評価を実 験後に得て議論しており，子どもからの情報をもとにオンラ インで行動を変えている訳ではない，また，事前に子どもの 性格や好みの情報をロボットに与えるという方法は，実際の 遊びの場面では現実的ではない，遊びながら子どもの情報を 獲得して，適応的に働きかけをするシステムが必要である.

そこで本研究では，ロボットが子どもと遊んでいる間に計 測できる子どもの行動指標から，遊びの好みや性格の傾向な どの子どもの情報を推定するシステムの開発を目的とする. そのため，遊び相手ロボットによる子どもの遊び実験を行 い，子どもの性格検査や遊びの好みとロボットから計測でき る行動指標との対応について調査し, 分析した。 そして行動 指標から推定可能と考えられる好みや性格について，ロボッ トと子どもの遊び場面での利用について議論する。

\section{2. 実 験 方 法}

\section{1 被 験 者}

子どもの遊びの好みとそれに伴う行動などの特徵量を検討 するため，5～6歳の子どもを対象にロボットとの 1 対 1 の遊 び実験を行った [3]．ロボットについての印象を統制するた め,被験者は初見の児童（平均 $=5.85$ 歳, $\mathrm{SD}=0.3$, 男児 7 人, 女児 5 人）を対象とした。このうち 1 人は実験が始まる前に ロボットに会うのを怖がって帰ったためデータから除外し， 
11 人のデータに関して分析を行った. 本実験は玉川学園倫理 委員会の承認を受けており, 被験児の保護者には書面と口頭 で実験の説明をして了承を得た上で実験を開始した。

\section{2 遊びロボットシステム}

本研究で使用したロボットプラットフォームは, 図1の “DiGORO”である. DiGOROは，家庭内で家事などを行うこ とを目的とする家庭用サービスロボットである，6自由度の 双腕アームと 1 自由度の腰, 3 本指のハンドを有し, その身体 性を生かして，身体や扮もちゃを使った高度な遊びができる。

また，頭部にはCCDカメラ（DFK31AU03，The Imaging Source社, 画角横方向 70deg, 縦方向 53deg) と赤外線 TOFカ メラ (SR4000, MESA社) が搭載されており [15], 人や物 体のオンライン学習や正確な認識が可能である [16]. 被験者 のデータを取得するためUSB 接続カメラ (HD Pro Webcam C910, Logicool社, 画角78deg) と TOFカメラ (Kinect, Microsoft社）をロボットの中央部に設置し被験児を撮影し た. USBカメラ・TOFカメラのいずれも $480 \times 640$ 画素で $1 \mathrm{~m}$ 程度の距離から撮影した。 USB カメラでは顔画像を取得 して顔認識ライブラリ（OkaoVison, Omron）で顔方向・顔 角度・笑顔度を $5 \mathrm{fps}$ で算出できる（図2）。図2の赤い四角 は認識された顔位置, 青い線分は鼻位置を認識映像から顔付 近を切り出して表示している.

ここで笑顔度とは，顔の口角の上がり具合やしわのでき 方などから Haar-like特徵量により, 認識対象者がどの程度 の笑顔を浮かべているかを 0 〜 100 の数值で示したものであ る [17]. 本研究ではこれらを子どもの行動の特徴量とした。

ロボットが多くの遊びに対応することは，前述の興味度の 視点で継続して子どもの興味を引くために重要である。本実 験では安全性の配慮から子どもが室内で着席して遊ぶ状況を 想定し, ロボットも移動せずに実験を行った，子どもとの遊 び相手として，ロボットは子どもとできるだけ長く遊び続け られる必要がある。そのためロボットが相手の状態や遊びの 状況に応じて, 遊びや行動を切り替えるシステムが提案され ている $[2,3]$. 阿部らは, 子どもの心的状態に関する状態遷

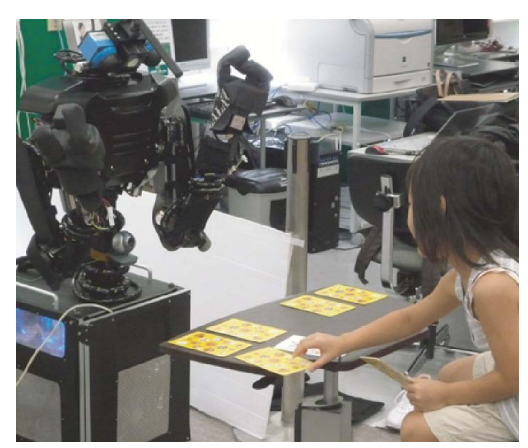

図1遊び相手として使用したロボットDiGORO

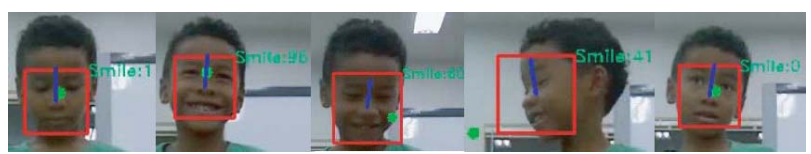

図2 顔認識システムにおける視線・表情認識

移を構成し, 状態推定アルゴリズムに基づき状態を推定して いる [3]. 更に推定された状態に基づいて「カードゲーム（神 経衰弱)」や「じゃんけん」,「絵本読み」などの遊びを切り 替えるシステムを提案している。本研究ではこのシステムを 用い，遊びを切り替えながらインタラクションを行なった。 神経衰弱ゲームは子どもの認知度が高く，ほぼすべての子が ルールを知っている若しくは簡単に理解できるため採用した.

\section{3 手 順}

実験では, 子どもが椅子に座ってロボットとテーブルを挟 んで対面し、ロボットと遊んだ（配置は図3参照）。部屋に は奥に仕切りがあり，ロボットの誤認識や動作の不具合に備 えて操作者が被験児に見えない位置に待機していた。ロボッ 卜は自律的に動作するが, 操作者は割込みでロボットを操作 できる。実験中は実験補助者が常に被験児に付き添ってい た。カードゲームではロボットがカードを指差し, 実験補助 者若しくは被験児がカードをめくった.

実験では，ロボットは子どもの表情，動きなどからロボッ トや遊びに対する興味の度合いを推定しながら行動を決定し

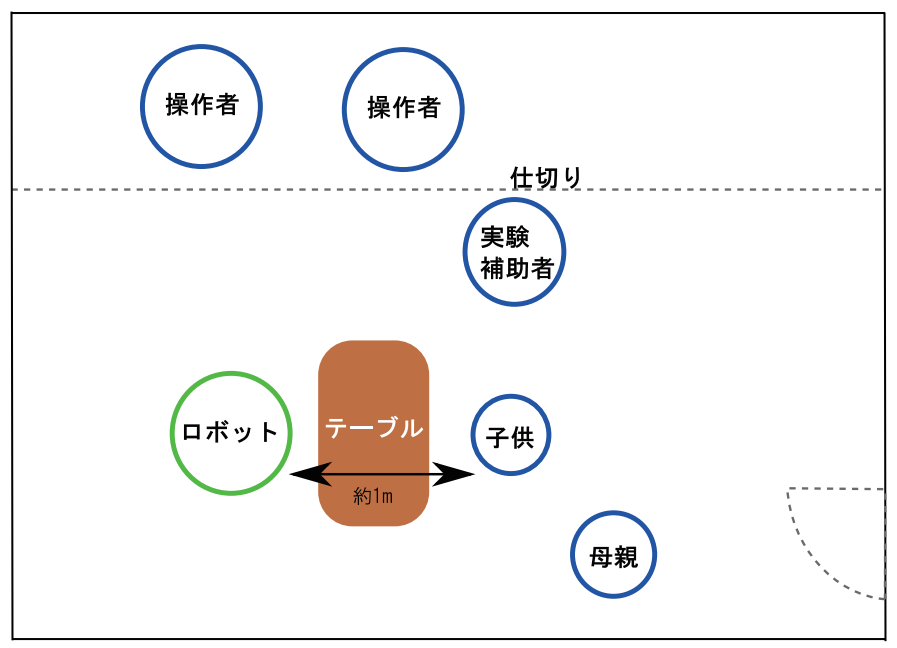

図3 実験配置図 
た. 行った遊びは神経衰弱, じゃんけん, 絵本読みの 3 種類 であった，実験の間，ロボットに取り付けたカメラで子ども の正面からの映像を取得し，行動をビデオとして記録し た。ロボットの処理に使用しているカメラ以外に, 子どもの 正面からの映像を取得できる位置に小型のカメラと Kinectを 置き, 子どもの様子をビデオに, さらに3 次元の動きをデー タとして記録した。こうした記録は，遊びに関する質問項目 の結果と共に解析し, 遊びの好みや性格と振る舞いを関連付 けるために利用した。 また, Kinectによる3 次元情報は, 子ど もの視線や動きの量・方向を定量的に求めるために使った.

実験は，子どもが入室してから，対話モジュールを使用し た慣らし (5 分), 遊び ( 25分), 退室という流れで行い, 実験時間は一人あたり最長 30 分とした。遊びはトランプの 神経衰弱とじゃんけん, 絵本読みを, 状況に応じて切り替え た．対話中など，テーブルや手先を見る必要のない時は，ロ ボットは顔追跡でアイコンタクトを行った．遊びの行動選択 はロボットが行動指標に基づいて自律的に行い, その行動の 実行タイミングのみはオペレータが遠隔操作で指示した。な お, このロボットシステムは, 子どもが興味を持って遊び続 けられることを目的として, 推定した子どもの興味度に基づ く行動選択モデルが実装されている。このモデルにより，子 どもからのロボットの印象評価が向上したという結果が得ら れた [3]．また，現在の技術では音声認識のみでのスムー ズな会話は困難であるため, オペレータが一部手動で操作を 行った。将来的には音声認識や実行タイミング決定はロボッ トが自律的に行う予定である.

\section{4 聞き取り調査（質問項目）}

遊び実験の終了後，被験児と保護者へ聞き取り調査を行っ た。更に保護者に対しては，対象児について13 項目の性格 的傾向を評価する TS 式幼児 ·坚童性格診断検査 [18］を実 施した.

被験児には，遊びについて好きな度合いに関する聞き取り 調査を行い，52種類の遊びそれぞれについて，「好き」·「普 通」·嫌い」・「知らない」(3, 2, 1, 0) の評価を得た。遊 びの一覧を表 1 に示す。因子分析では計算上の都合から同じ 回答であった 18 項目を除外して34項目（表1 G01〜 G34） に関して分析した。評価は表2のようになった。表2中の
表1 遊び質問項目

\begin{tabular}{|c|c|}
\hline 遊び ID & 遊び \\
\hline G01 & あっち向いてホイ \\
\hline G02 & おままごと \\
\hline G03 & カードゲーム (トレーディングカード) \\
\hline G04 & サッカー \\
\hline G05 & ピアノ・歌・音楽 \\
\hline G06 & プラレール \\
\hline G07 & お人形遊び \\
\hline G08 & ロボット、人形で戦いごっこ \\
\hline G09 & 絵本読み \\
\hline G10 & 戦いごっこ \\
\hline G11 & ごっこ遊び \\
\hline G12 & 小さい動物と遊ぶ \\
\hline G13 & お絵かき \\
\hline G14 & あやとり \\
\hline G15 & ブロック \\
\hline G16 & 折り紙、粘土、工作 \\
\hline G17 & パズル \\
\hline G18 & なぞなぞ \\
\hline G19 & お手玉 \\
\hline G20 & カルタ取り \\
\hline G21 & ミニカー \\
\hline G22 & 塗り絵 \\
\hline G23 & じゃんけん \\
\hline G24 & 虫取り \\
\hline G25 & 縄跳び \\
\hline G26 & かけっこ \\
\hline G27 & 椅子取りゲーム \\
\hline G28 & かくれんほ \\
\hline G29 & 積み木 \\
\hline G30 & ブランコ \\
\hline G31 & しりとり \\
\hline G32 & 編み物、ビーズ \\
\hline G33 & スイミング \\
\hline G34 & けいどろ \\
\hline G35 & 7 並べ \\
\hline G36 & アイロンビーズ \\
\hline G37 & アルプスいちまんじゃく \\
\hline G38 & 野球 \\
\hline G39 & ドッジボール \\
\hline G40 & ジェスチャーゲーム \\
\hline G41 & じじ抜き \\
\hline G42 & テレビゲーム \\
\hline G43 & ばば抜き \\
\hline G44 & ハンカチ落とし \\
\hline G45 & 花一夕 \\
\hline G46 & マイムマイム \\
\hline G47 & あぶくたった \\
\hline G48 & 鬼ごっこ \\
\hline G49 & 神経衰弱 \\
\hline G50 & 鉄棒 \\
\hline G51 & 伝言ゲーム \\
\hline G52 & 大きい動物と遊ぶ \\
\hline
\end{tabular}

\section{表2 子どもの遊びに関する回答}

\begin{tabular}{|c|c|c|c|c|c|c|c|c|c|c|c|c|c|c|c|c|c|c|c|c|c|c|c|c|c|c|c|c|c|c|c|c|c|c|c|}
\hline \multirow{2}{*}{ ID } & \multirow{2}{*}{ gender } & \multicolumn{34}{|c|}{ item ID } \\
\hline & & $\mathrm{G} 01$ & $\mathrm{G} 02$ & G03 & G04 & G05 & G06 & G07 & $\mathrm{G} 08$ & G09 & G10 & G11 & G12 & G13 & G14 & G15 & G16 & G17 & G18 & G19 & G20 & G21 & G22 & G23 & G24 & G25 & G26 & G27 & G28 & G29 & G30 & G31 & G32 & G33 & G34 \\
\hline $\mathrm{C} 01$ & $\mathrm{~F}$ & 1 & 1 & 2 & 1 & 1 & 1 & 1 & 1 & 2 & 1 & 1 & 3 & 3 & 3 & 2 & 2 & 3 & 3 & 3 & 3 & 1 & 1 & 1 & 3 & 3 & 1 & 3 & 3 & 1 & 2 & 3 & 3 & 1 & 3 \\
\hline $\mathrm{C} 02$ & M & 1 & 1 & 2 & 3 & 2 & 3 & 1 & 3 & 2 & 3 & 1 & 2 & 3 & 3 & 3 & 3 & 2 & 3 & 1 & 2 & 3 & 1 & 3 & 3 & 3 & 1 & 1 & 2 & 1 & 3 & 3 & 2 & 3 & 2 \\
\hline $\mathrm{C} 03$ & F & 3 & 2 & 2 & 1 & 2 & 2 & 2 & 1 & 2 & 3 & 2 & 2 & 3 & 3 & 2 & 3 & 3 & 2 & 2 & 3 & 2 & 3 & 3 & 1 & 3 & 3 & 3 & 3 & 2 & 3 & 3 & 3 & 3 & 3 \\
\hline C04 & M & 2 & 2 & 1 & 3 & 3 & 3 & 1 & 2 & 3 & 3 & 3 & 1 & 3 & 2 & 3 & 3 & 3 & 3 & 2 & 2 & 3 & 3 & 3 & 3 & 2 & 3 & 1 & 3 & 3 & 3 & 3 & 0 & 1 & 2 \\
\hline C05 & F & 2 & 2 & 1 & 1 & 3 & 1 & 2 & 1 & 3 & 1 & 2 & 3 & 2 & 2 & 2 & 3 & 2 & 3 & 2 & 3 & 1 & 2 & 2 & 3 & 3 & 3 & 2 & 3 & 2 & 3 & 2 & 3 & 1 & 0 \\
\hline C06 & M & 3 & 3 & 1 & 1 & 3 & 3 & 3 & 1 & 3 & 3 & 3 & 3 & 3 & 1 & 3 & 3 & 3 & 3 & 1 & 1 & 3 & 3 & 3 & 3 & 1 & 3 & 3 & 3 & 3 & 3 & 3 & 3 & 3 & 3 \\
\hline $\mathrm{C} 07$ & F & 2 & 3 & 3 & 1 & 3 & 2 & 3 & 1 & 3 & 1 & 3 & 3 & 3 & 1 & 3 & 3 & 3 & 2 & 1 & 2 & 2 & 3 & 3 & 2 & 3 & 3 & 2 & 3 & 3 & 2 & 3 & 3 & 2 & 0 \\
\hline C08 & M & 2 & 3 & 3 & 2 & 3 & 2 & 2 & 3 & 3 & 3 & 1 & 2 & 3 & 2 & 2 & 3 & 3 & 2 & 2 & 3 & 3 & 2 & 3 & 3 & 3 & 3 & 3 & 3 & 3 & 3 & 3 & 1 & 0 & 2 \\
\hline C09 & M & 3 & 3 & 3 & 3 & 1 & 3 & 3 & 3 & 3 & 3 & 3 & 3 & 3 & 2 & 3 & 3 & 3 & 3 & 2 & 3 & 3 & 3 & 3 & 3 & 2 & 3 & 3 & 3 & 3 & 3 & 3 & 3 & 3 & 0 \\
\hline $\mathrm{C} 10$ & M & 3 & 1 & 3 & 2 & 3 & 3 & 1 & 3 & 3 & 3 & 2 & 3 & 3 & 3 & 2 & 3 & 3 & 3 & 2 & 2 & 2 & 3 & 3 & 3 & 3 & 3 & 3 & 3 & 2 & 3 & 3 & 3 & 3 & 3 \\
\hline C11 & M & 3 & 3 & 3 & 3 & 3 & 3 & 1 & 3 & 3 & 3 & 3 & 3 & 3 & 3 & 3 & 3 & 3 & 3 & 2 & 3 & 3 & 3 & 3 & 2 & 1 & 3 & 3 & 3 & 3 & 3 & 3 & 0 & 3 & 3 \\
\hline $\mathrm{C} 12$ & $\mathrm{~F}$ & 2 & 3 & 2 & 1 & 3 & 3 & 3 & 1 & 3 & 1 & 3 & 3 & 3 & 3 & 3 & 3 & 3 & 3 & 2 & 3 & 3 & 3 & 3 & 1 & 2 & 3 & 3 & 3 & 3 & 3 & 3 & 0 & 3 & 0 \\
\hline
\end{tabular}


item IDは表1の遊びIDに対応している．実際にロボットが 子どもと遊んだ神経衰弱（G49）は，ほぼすべての子どもが 知っていると回答した。 また，IDのC01〜C 12 は被験児の IDである。

子どもの性格について, 保護者が回答する形式で, 質問紙 法の性格診断テストである TS 式性格診断検査を実施した [18]. TS 式性格診断検査は, 未就学児童の性格について客観 的に把握し，養育上必要な配慮を判断することを目的とした ものである. その結果を, 表3に示す. 表3 中の項目 IDは, 表3右側に示したものである，検査には，顕示性・神経質・ 情緒不安·自制力 · 依存性 ·退行性 - 攻撃性 · 社会性 · 家庭 適応 ·学校適応 ·体質傾向の 11 項目, さらに, 顕示性・神 経質・情緒不安・自制力・依存性・退行性・攻撃性を総合し た個人的安定, 社会性 - 家庭適応 - 学校適応を総合した社会 的安定の 2 項目がある. それぞれの項目の結果は 1 99で表 わされ, 值が低いほど精神的に不安定であり, 何らかの配慮 が必要であるとされる.

\section{3. 結 果}

遊びの実験は被験児の意思によって終了するか，30分を 超えた段階で実験者が終了を促した。また，遊びを行う前に 子どもを実験環境に慣れさせるために慣らし時間を 5 分程度 設けた。この時に観測された行動の傾向と性格診断検査や遊 びの好みに関するアンケートの結果との関係について得られ た結果を示す.

\section{1 行動の傾向と性格傾向の関係性}

慣らしの段階における OkaoVisionによる被験児の顔方向 の観測值は図4 (a) のようになった。ここで横軸は時間であ り, 縦軸の正の方向は保護者を, 負の方向は実験補助者に向 く顔の角度を表わしている。この図の（a）は顔の向きの測定 值そのもので, 図4 (b) では子どもが意図的に振り向いた夕 イミングをより明確に検出するために笑顔度も考慮した振り 向き度である。

振り向き度 $=$ 笑顔度 $\times$ 顔方向

表3 児童性格検査

左 : 各児童の算出スコア, 右 : 各項目

\begin{tabular}{|c|c|c|c|c|c|c|c|c|c|c|c|c|c|c|c|}
\hline \multirow{2}{*}{ ID } & \multirow{2}{*}{ gender } & \multirow{2}{*}{ age } & \multicolumn{13}{|c|}{ personality item ID } \\
\hline & & & $\mathrm{P} 01$ & $\mathrm{P} 02$ & $\mathrm{P} 03$ & P04 & P05 & P06 & $\mathrm{P} 07$ & P08 & P09 & P10 & P11 & P12 & P13 \\
\hline C01 & $\mathrm{F}$ & 5.1 & 30 & 10 & 25 & 15 & 60 & 70 & 20 & 99 & 99 & 50 & 60 & 20 & 40 \\
\hline $\mathrm{C} 02$ & M & 5.08 & 1 & 50 & 60 & 20 & 90 & 35 & 20 & 99 & 30 & 99 & 60 & 20 & 60 \\
\hline $\mathrm{C} 03$ & $\mathrm{~F}$ & 5.11 & 15 & 65 & 60 & 20 & 75 & 35 & 30 & 99 & 60 & 99 & 80 & 35 & 85 \\
\hline $\mathrm{C} 04$ & M & 5.02 & 50 & 80 & 60 & 30 & 45 & 25 & 40 & 99 & 99 & 99 & 80 & 55 & 99 \\
\hline $\mathrm{C} 05$ & $\mathrm{~F}$ & 6.03 & 10 & 75 & 45 & 5 & 90 & 50 & 15 & 99 & 30 & 99 & 75 & 30 & 55 \\
\hline C06 & M & 6.05 & 5 & 60 & 99 & 10 & 40 & 85 & 10 & 99 & 80 & 45 & 99 & 30 & 80 \\
\hline $\mathrm{C} 07$ & $\mathrm{~F}$ & 5.08 & 80 & 50 & 35 & 99 & 20 & 70 & 99 & 10 & 30 & 10 & 99 & 70 & 10 \\
\hline C08 & $\mathrm{M}$ & 6.01 & 40 & 75 & 80 & 75 & 80 & 95 & 40 & 65 & 99 & 99 & 55 & 85 & 99 \\
\hline $\mathrm{C} 09$ & $\mathrm{M}$ & 5.1 & 50 & 99 & 80 & 40 & 30 & 50 & 40 & 99 & 30 & 15 & 60 & 55 & 40 \\
\hline $\mathrm{C} 10$ & $\mathrm{M}$ & 5.09 & 99 & 99 & 80 & 99 & 99 & 95 & 99 & 35 & 99 & 50 & 80 & 99 & 85 \\
\hline C11 & $\mathrm{M}$ & 5.09 & 50 & 50 & 80 & 40 & 75 & 70 & 80 & 99 & 60 & 99 & 25 & 70 & 85 \\
\hline $\mathrm{C} 12$ & $\mathrm{~F}$ & 5.1 & 20 & 50 & 5 & 20 & 60 & 85 & 60 & 15 & 40 & 50 & 40 & 35 & 20 \\
\hline
\end{tabular}

\begin{tabular}{l|l}
\hline 項目 ID & 診断項目 \\
\hline P01 & 顕示性が強い/顕示性なし \\
P02 & 神経質/神経質ではない \\
P03 & 情緒不安定/情緒安定 \\
P04 & 自制力なし/自制力がある \\
P05 & 依存的/自立的 \\
P06 & 退行的/生産的 \\
P07 & 攻撃・衝動的/温和·理性的 \\
P08 & 社会性なし/社会性がある \\
P09 & 家庭不適応/家庭適応 \\
P10 & 学校不適応/学校適応 \\
P11 & 体質的不安定/体質的安定 \\
P12 & 個人的不安定/個人的安定 \\
P13 & 社会的不安定/社会的安定 \\
\hline
\end{tabular}

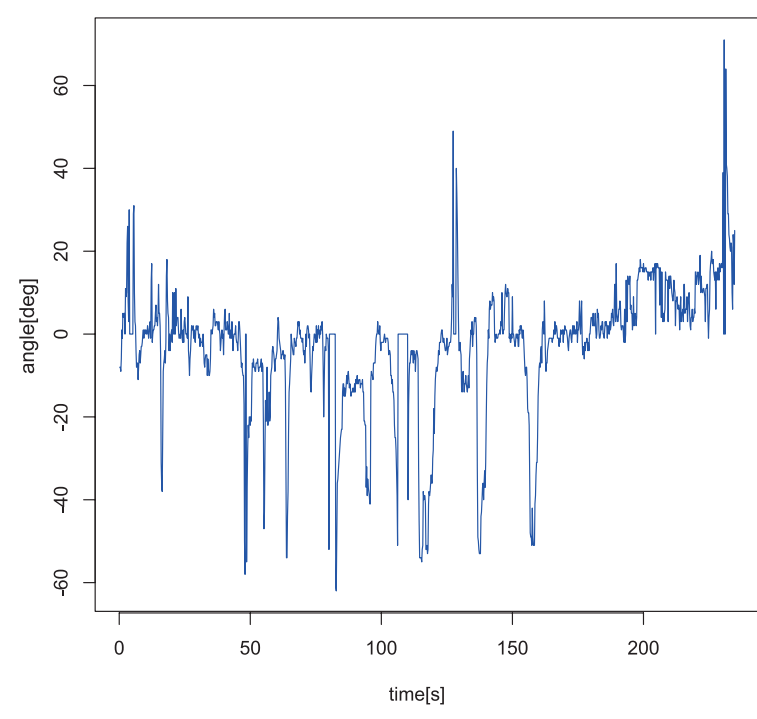

(a) OkaoVisionによる顔の方向観測値

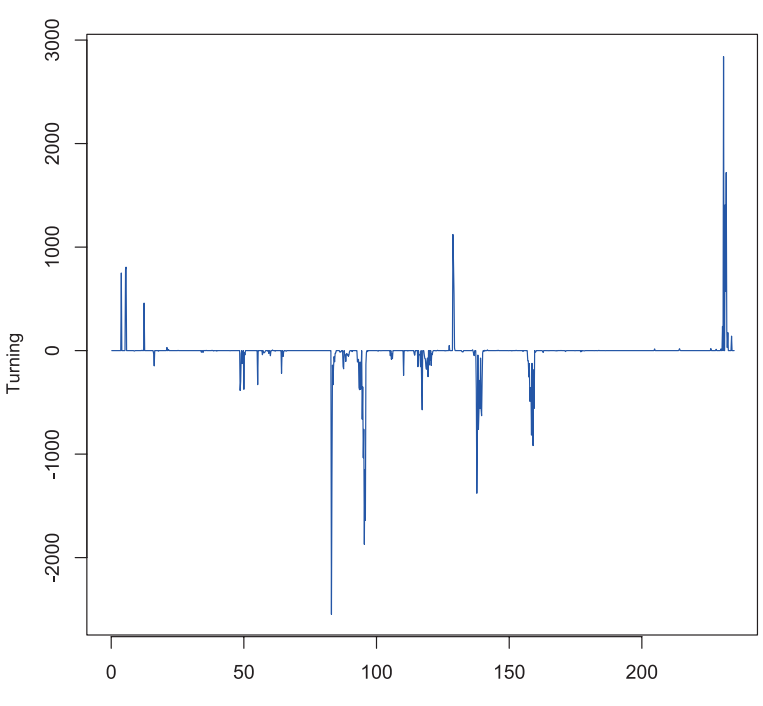

(b) 振り向き度 $=\underset{\text { time }}{=}$ 笑顔度 $\times$ 顔方向

図4ロロボットによる対象被験児の観測情報に関する時間変化 
これにより，保護者を頻繁に振り向く傾向が強い子どもと そうでない子どもが区別できると考えられる.

実際の遊びの場では，保護者や保育士は子どもの行動から 遊びの好みだけではなく性格的傾向についても推測している と考えられる，そこで，本研究でも実験中の子どもの行動を 観察して性格的傾向と関係のあると思われる特徵的な行動を 抽出することで，ロボットによる推定の方法を検討する，

性格検査によって家庭適応のスコアが低い子どもには実験 中何度も保護者を振り返って笑いかける, 話しかけるなどの 行動が特に顕著に見られた。この傾向は7名の評価者（平均 年齢 $=22.3$ 歳, $\mathrm{SD}=2.21$, 女性 5 名）にロボットに装備した webカメラで記録したビデオを見てもらい, 子どもが振り 返っていると判断できるタイミングでボタンを押してもらっ た回数から判断した。振り返り回数の少ない子どもを no-turn 群 (6名), 少し振り返っている,または頻繁に振り返っ ている子どもを turn群 (5名) とした。図 5 は振り返りの多寡 に対する性格診断検査の家庭生活に関するスコアの関係を示 している. 丸は対象児のスコア, 実線は中央值, 破線は平均 值を示している。一人の被験者については実験の最初の部 分である慣らし段階で，ロボットを怖がり入室をためらい, 振り返りを確認できなかったため分析から除いた。これら 2群の家庭適応のスコアについて順位和検定を行ったところ， no-turn 群で有意にスコアが高かった $(\mathrm{W}=28, \mathrm{p}<0.05$, 両側 $)$.

ロボットの観測した振り向き度の時系列に含まれる特徵量 を抽出するため, すべての子どもの振り向き度の時間変化を 正負方向で分け, 各 1 次から 4 次の中心モーメントを算出し て説明変数とし, 性格傾向の点数を目的変数として重回帰分 析を行った．ステップワイズによる変数選択を行っている。 その結果, 家庭適応 /不適応の点数に関して, 正方向（母 親を振り向いている時）のみに 3 次・4次モーメントの係数 で有意性 $\left(2\right.$ 次 : $\beta_{2}=-2.4 \mathrm{e}-04, \mathrm{p}<0.1,3$ 次 : $\beta_{3}=-4.3 \mathrm{e}-07$, $\mathrm{p}<0.05,4$ 次 : $\left.\beta_{4}=-1.4 \mathrm{e}-10, \mathrm{p}<0.05\right)$ が得られた. この時 の決定係数は $\mathrm{R}^{2}=0.73$ であった。他の性格傾向に関しては 有意な結果が見られなかった。

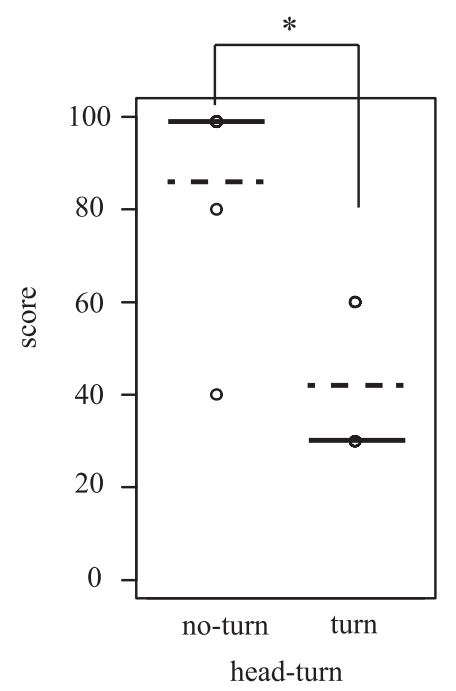

図5＼cjkstart対象児の振り返り有無と性格スコアの関係
さらに，評価者がボタンを押したタイミングを時系列デー タとして保存し, 移動平均フィル夕をかけたものを評価者に よる観測とした。図6の青線，緑線，赤線はそれぞれ振り向 き度，閾值処理をした振り向き度，振り向きに関する評価者 の平均を示している。振り向き度の絶対值に関して標準偏差 值 SD を計算し， $\pm 20 S D$ の值を閾值とした。この評価者によ る観測とロボットの観測量の整合性を確認するために, 各子 どもにつき評価者の観測とロボットの観測量の相関係数を算 出した。この計 11 個の相関係数について検定を行ったとこ ろ, 有意な正の相関が得られた（W=66, $\mathrm{p}<0.001$, 順位和 検定, 中央值 $=0.149)$. また, 評価者がビデオを見て振り返っ たと判断した（ボタンを押した）回数と，ロボットの観測結 果の間で順位和相関を計算したところ，3次モーメントが最

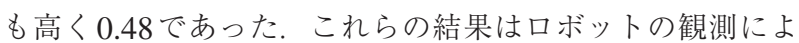
る振り向き度の妥当性を示している.

\section{2 遊びの傾向と性格傾向の関係性}

表2の遊びの好みの回答に関して因子分析を行った。因子 分析からは，子どもの好きな遊びの偏りが見て取れると期待 される，そこで，それぞれの遊びに何らかの因子が存ること を仮定し，それらの因子と性格的要素の関連を調べるため に，ケースを各被験者，変数を各遊びとして表 2 の結果を因 子分析した。結果を図 7 に示す。なお，「好き」・「普通」・「嫌 い」の值はそれぞれ $3,2,1$,「知らない」の值を 2 と仮定し， 因子分析には最小二乗法, 回転にはVarimax 法を用いた。
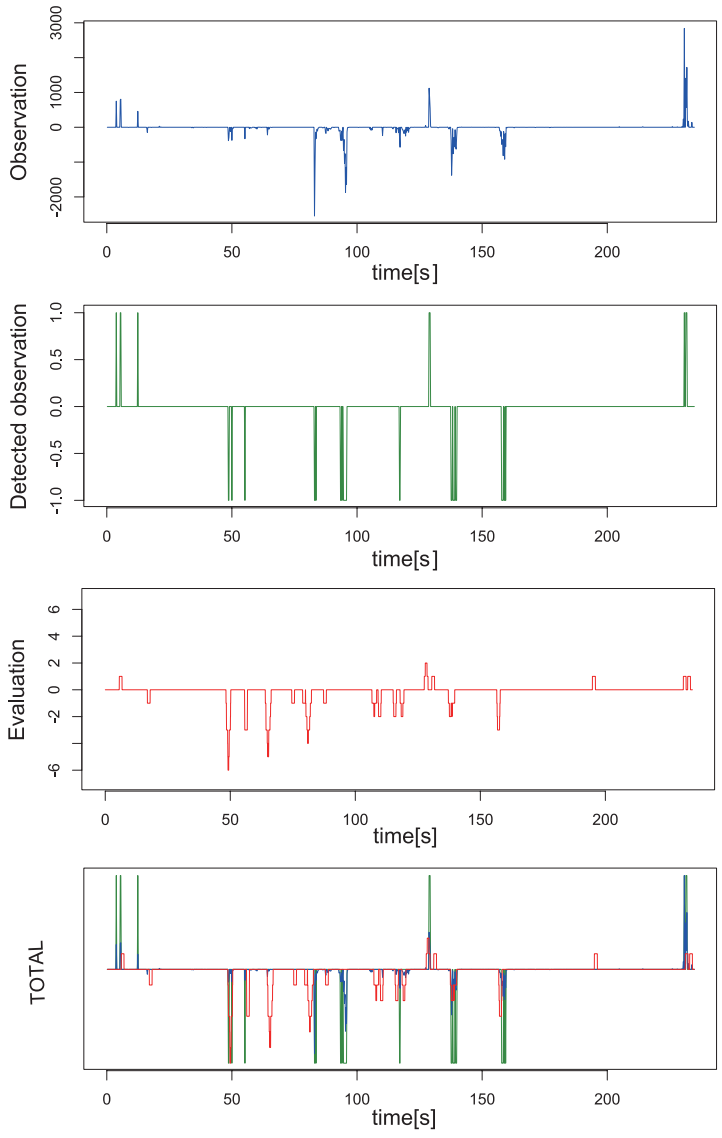

図6ロロボットの振り向き観測と評価者による観測 


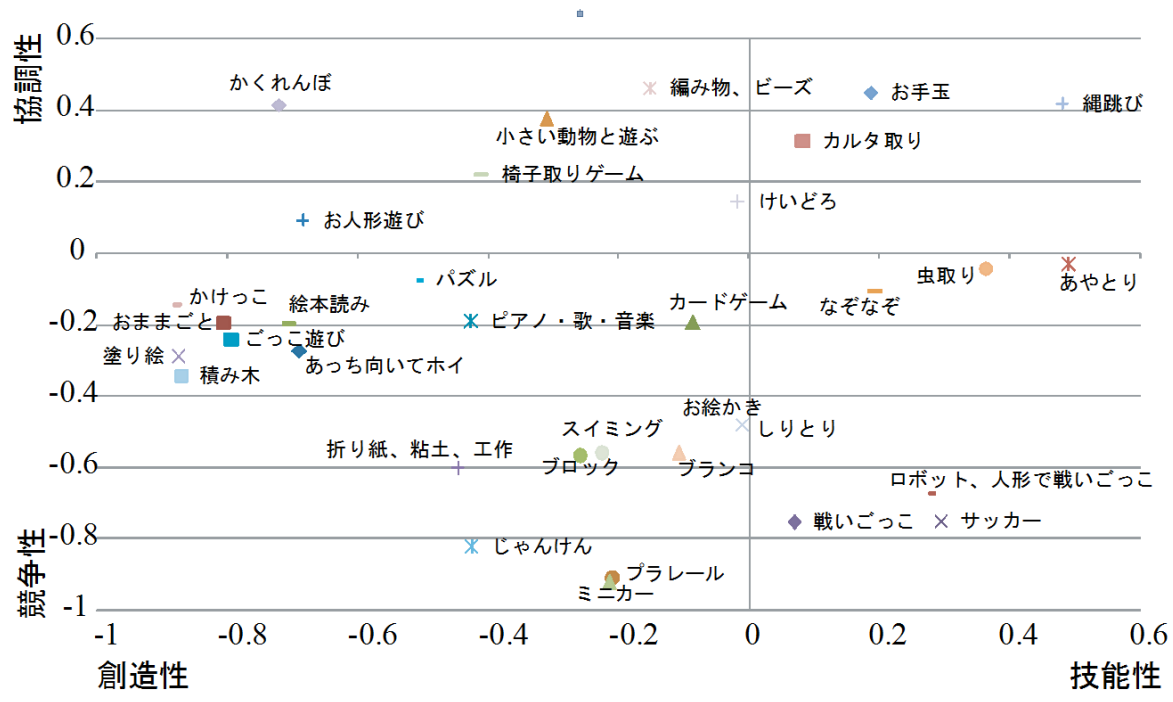

図7 因子分析結果

選んだ34種類の遊びからは2個の因子が抽出された。図7の ように，第一因子は正の方向には「小さい動物と遊ぶ」など があり，これらは面倒をみる，協力して遊ぶなどの協調性の 必要なものであると考えられる。逆に負の方向には「サッ カー」,「戦いごっこ」などがあり,これらは勝敗が分かれる, 擬似的に対立するなどの競争的な要素の強いものである. よって, この因子を「協調 - 競争性」と呼ぶ. また, 第二因 子の正の方向には「あやとり」,「縄跳び」などがあり, これ らは知識や技能を必要とし, 一定のルールが存在するもので あると考えられる。これは対立して負の方向には「おまま ごと」,「塗り絵」などがあり, 比較的ルールが少なく, 能力 などを気にせずに自由に，または創造的に遊ぶことのできる ものであると考えられる，よって，この因子を「技能－創造 性」と呼ぶ. また, 結果の解析に当たり便宜的に図7の象限 を第1象限から順に「協調 · 技能」「協調 · 創造」「競争・創 造」「競争・技能」と呼ぶ.

なお，それぞれの遊びの因子について，一見正しくないよ うに見えるものがいくつか存在する。例えば「かくれんぼ」 は, 競争性ではなく協調性を持つという結果になっている. これは, 大人の場合は見つからないように隠れる競争性の高 い遊びであると解釈することが多いが, 子どもにとっては「自 分を見つけてほしい」など，相手とのコミュニケーションを 意識した協調性の高い遊びであるという解釈も考えられ る。遊び実験中にも, 子どもが意図的にロボットから隠れ, ロボットに見つけてもらおうとしたケースが存在した。これ は，ロボットと競うことを意罒した競争的な態度ではなく， ロボットとのコミュニケーションを図ろうとした協調的な態 度であると考えられる。このように大人と子どもでは, それ ぞれの遊びに対する解釈に少なからず差異が存在する.

また,「かけっこ」は「かくれんぼ」と同様に競争的な遊 びというよりは, 一緒に走って楽しむ遊びであるという解釈 もあると考えられる。今回は被験者が少ないことの影響もあ り, 必ずしも安定した結果とは言えないし, 因子の名前につ
いても検討の余地がある. しかし，大学生を対象とした子ど も時代の遊びの好みに関する報告では, 造形系や技能・操作 系などの因子を挙げており [19]，本研究で取り上げた軸と 類似しているため, ある程度の信頼性はあると考えられる。

因子負荷量を子どもが「好き」と回答したものを 1 ,「嫌い」 としたものを-1で重みづけし，上記の4象限それぞれの重 心を求めた。 なお, 各象限の重心がその象限を飛び出し「嫌 い」の方に重心が傾いている場合, その象限の遊びが好きで

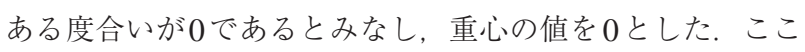
で4象限に分けて重心を求めたのは，もし因子全体で協調性 と競争性を分けずに重心を求めた場合, 協調性の高い遊びが 好きな子どもならば競争性の高い遊びは好まないという結果 になってしまう可能性があるためである.

図7の各象限ごとに, 表3の性格診断検査の結果との関係 性を考察する，各象限を好む子どもと好まない子どもとで性 格診断検査の各項目について $\mathrm{p}<0.05 て ゙ \mathrm{t}$ 検定を行い, 有意差 があるものを求め, 表 4 にまとめた。 その結果, どの象限に おいても，各遊びを好む子どもは好まない子どもより高いス コアを持ち, 性格が安定していることが分かる。 また, 男女 に差があることは，第2因子（強調一競争）の重心を男女別 で見て, その值について $\mathrm{p}<0.05 て ゙ \mathrm{t}$ 検定を行ったところ有意 差が認められたことからも裏づけられる。

\section{3 行動と遊びの好みの関係性}

遊びの好みに関する特徵量に関して, 3.1 と同様に行動の 特徵量を説明变数として重回帰分析を行ったが, 有意な結果 は得られなかった，遊びの創造性・競争性の特徵量について 2群に分け，実験において絵本読みを行っている時の子ども の行動の特徵量 (gaze, stare) の平均值を計算し $\mathrm{t}$ 検定 $(\mathrm{p}<0.05)$ を行ったところ, 有意な差が認められた。この時のstare とは 子どもの視線方向の安定性を表しており, 遊びの創造性・競 争性の特徴量が大きい子どもはそうでない子どもに比べて視 線方向の動きが有意に少なかった。 
表4＼cjkstart遊びの好みと性格スコアの関係性

\begin{tabular}{|c|c|c|c|c|c|c|}
\hline 象限 & 好む子供 & 好まない子供 & 好む男児 & 好まない男児 & 好む女児 & 好まない女児 \\
\hline \multirow{2}{*}{ 協調 · 技能 } & \multirow{2}{*}{\multicolumn{2}{|c|}{-}} & 情緒安定 & 情緒不安定 & \multirow{2}{*}{\multicolumn{2}{|c|}{-}} \\
\hline & & & 生産的 & 退行的 & & \\
\hline \multirow{2}{*}{ 協調 · 創造 } & \multirow{2}{*}{ 生産的 } & \multirow{2}{*}{ 退行的 } & 自制力あり & 自制力なし & \multirow{2}{*}{\multicolumn{2}{|c|}{-}} \\
\hline & & & 神経質でない & 神経質 & & \\
\hline \multirow{4}{*}{ 競争 · 創造 } & 顕示性なし & 顕示性が強い & \multirow{4}{*}{\multicolumn{2}{|c|}{ - }} & \multirow{4}{*}{ 温和 - 理性的 } & \multirow{4}{*}{ 攻撃·衝動的 } \\
\hline & 自制力あり & 自制力なし & & & & \\
\hline & 温和 - 理性的 & 攻撃· 衝動的 & & & & \\
\hline & 個人的安定 & 個人的不安定 & & & & \\
\hline \multirow{3}{*}{ 競争·技能 } & 情緒安定 & 情緒不安定 & \multirow{3}{*}{\multicolumn{2}{|c|}{-}} & \multirow{3}{*}{\multicolumn{2}{|c|}{-}} \\
\hline & 神経質でない & 神経質 & & & & \\
\hline & 個人的安定 & 個人的不安定 & & & & \\
\hline
\end{tabular}

\section{4. 議論・考察}

家庭内で人と暮らすロボットを目指し，身体性を生かして 子どもと遊ぶ，遊び相手ロボットを用いて子どもとの遊び実 験を行った。 それと同時に, 遊びにおける他者の心的状態と いう, 計測困難な状態量を扱うため, 子どもの遊びの好みの アンケートや性格診断検査を行い, 子どもの行動との関係性 を調査した。

\section{1 子どもの情報の推定法}

本研究ではロボットに装備したKinect と顔認識の結果か ら性格と遊びの好みを推定する手法を提案し, その手法が有 効であることを示した，実社会におけるコミュニケーショ ンでは，人は相手の表情や行動を一定時間観察することで, 相手の性格や好みを把握していると思われる。本研究では, ロボットも同様に，一緒に遊びながら子どもの表情や行動を 推定することができれば, 提案すべき遊びの種類や会話など の働きかけをより効果的に選択できると考えた，子どもと口 ボットの遊びに関する先行研究からは, 例えば興味度 $[1,2]$ や, 対人感覚 [3], 新奇性と親近感 [4] など多くの要素が 子どもの視線の向きと関連して報告されており, 本研究でも 視線の向きを重視して分析した。遊びには興味度で表わされ る「遊びへの興味や飽き」という要素の他に，ロボットへの 視線の頻度で表わされる「ロボットへの対人感覚」という要 素が存在する [3]. ロボットの振る舞いが他者モデルに基づ けば, 子どものロボットへの対人感覚を維持できることが示 されている。

\section{2 遊びの好みの推定}

遊びの好みに関する今回の分析からは，遊びの好みによっ て特徵的な行動指標が存在することや, 性別による好みの違 いがあることが示された，結果は子どもが創造性の遊びを好 むかどうかは, 絵本を注視する割合から推定できることを示 している。また，協調性と競争性の遊びの好みに関しては， 男女差が認められた。性格の男女差については多くの文献 で指摘されており, 男性にとって競争性が優位であるなど の普遍的な性格傾向が存在する [20]. 他の霊長類に関して も, オスはメスに比べ荒っぽい遊びを好む傾向にある [21].
子どもの遊びの好みを把握する上で, 性別による生物学的な 影響は避けられない.

\section{3 性格の推定}

性格診断検査のスコアに対する回帰分析の結果から, 家庭 適応に関する予測能力が高く，ロボットの観測による推定が 有効であることが明らかとなった。また家庭適応に関して, 振り返り行動との関係（図 5), ロボットによる行動観測と の関係（図6）から, 振り返り行動の関与が強く示唆された。 今回の調査では，ロボットの観測指標の中心モーメントを説 明変数として用いたが, 他の性格傾向との有意性は観測され なかった，本研究により，ロボットによる性格の傾向の推定 システムの可能性を示した，家庭適応と振り返りの傾向は， 親子の関係性を測る尺度になりうる。家庭適応のスコアは, 子どもが家庭内で心理的に安定しているかを推測するものと されており，養育者の顔色をうかがう傾向が関与すると考え られる [18].これまでの心理学的な研究では，母子間に限 らず，存在価值を確認する再確認行動について議論されてい る [22]. 本研究では対象児の養育者に対する振り向き行動 との関係性が見られたが，これも子どもが行う自身の存在価 值に関する確認行動であると解釈できる，従来の多くの研究 ではその指標として評価者の主観による評価值を用いてい る。しかし本研究で示したロボットによる観測は, ここで注 目する性格傾向に関する客観的な評価方法としての可能性を 示している.

今回の結果は, 社会心理学的な応用についても重要な位置 を占めるものである。過去の研究から, 性格に関する質問項 目によって家庭生活や学校生活における適応性の予測をする 試みに関して報告がなされている [23].ささらに，得られた 性格に関する情報を元に，ロボットを用いた遊戯療法などの 形で応用できる可能性もある.

本研究における遊び相手ロボットは，親あるいは養育者が 忙しくしている家庭で，一時的な保育の代行者としての playmateが実用的ではないかと考える，対人感覚を持たせ て長時間子どもの興味を引きつけて遊び相手として機能しつ つ, 子どもの発育の責任をもつ養育者には検知した状況を報 告する「発達の支援装置」あるいは「一時的代行装置」とし ての役割である。すなわち, 子どもの行動からその状況を継 
続的に推定する, さらには保護者が外部の専門家との相談を 行う場合にはその根拠となる情報を提供するというような利 用方法である。そのようなシステムとして機能するために は, 現状では検出できる性格特徵が不足であり, さらに今後 の実現に向けた取り組みが必要である.

\section{4 今後の展望}

本研究では, 対人感覚は子どもの興味を持続させようとす るロボットの適切な働きかけによって維持されると考え, これを実現するシステムのための基礎的検討を行った，子ど もは，相手が自身の好みに合った遊びなどの行為を継続して 働きかけてくる間に，相手が自身のことを理解していると考 える信頼感，好ましい遊びをしてくれるという親近感のよう

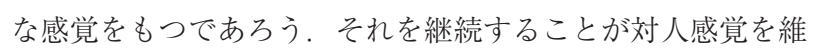
持し, 結果として飽きのこない遊び相手につながると考える.

また，より多くの子どもの性格と行動デー夕，更にその効 果の評価を検討する必要があり, 発達支援の装置としての実 現には多くの課題が残っている. 本研究はその初期の試みと いう位置づけとなる。今回行った実験ではサンプル数が少な く，多くの被験者に聞き取り調査と遊び実験などを継続して 行う必要がある。また，短時間に行う実験室での実験と異な り，家庭ではロボットと子どもが長期的に関わっていくこと が想定される。 そこで, 長期間の情報から子どもの好みを把 握していくことが有効であると考えられる，さらに，子ども がロボットに慣れる早さなどがそれぞれ異なるなどの予想か ら, 本研究ではロボットとの実験が初めての子どものみで分 析を行った。今後は保育士などの人間との反応の違いや 2 回 目以降の実験に対する反応も分析することを検討する.

\section{5. 結 論}

本研究では, 家庭内で人と暮らすロボットを目指し, 遊び 相手ロボットを用いて子どもとの遊び実験を行った。子ども の性格や好みに応じた遊びシステムを構築するための基礎研 究として, 別に行った児童性格検査の結果との関係性の有無 について調査した，本研究により各性格スコアと遊びの好 み，またロボットから観測した視線や表情に関する值との関 係が存在することが明らかとなった。

本研究で使用したロボットシステムは, 身体機構や計算処 理に高スペックを必要とするため, 即現実の応用としては費 用やメンテナンスの面で難しい. しかし最近のネットワーク やクラウド技術の進歩により処理能力の壁はかなり低くなっ てきており, 行動観察に必要な機材は低価格のカメラで実現 できる可能性がある。

\section{謝 辞}

本研究は, 科研費 (基盤 (C) 23500240) 及び新学術領域研 究「伝達創成機構」（領域番号 4103）課題番号 21120010, 若手研究 (B) 22700225 の助成を受け実施したものである.

\section{参 考 文 献}

［1］下斗米貴之, 阿部香澄, 岩崎安希子, 長井隆行, 大森隆司： ロボットによる子どもの興味度の推定, 第 13 回日本感性 工学会大会予稿集, F24, 2011.

[2] Shimotomai, T., Abe, K., Yokoyama, A., Nagai, T., and Omori, T.: Estimation of children's interest dynamics while communicating with robots, Proc. of International Conference of Cognitive Neurodynamics, P15, 2011.

[3] 阿部香澄, 岩崎安希子, 中村友昭, 長井隆行, 横山絢美, 下斗米貴之, 岡田浩之, 大森隆司: 子どもと遊ぶロボット： 他者の状態推定に基づく行動決定モデルの適用, HAIシン ポジウム, I-2B-3, 2011

４4］高橋英之，宮崎美智子，岡田浩之，大森隆司：「新奇性」 と「親近性」の軸から子どもとロボットの関係性を捉え る, HAIシンポジウム 2011, I-2B-2, 2011.

[5] Castellano, G., Pereira, A., Leite, I., Paiva, A., and McOwan, P.W.: Detecting user engagement with a robot companion using task and social interaction-based features, Proc. of International Conference on Multimodal Interfaces, pp.119-126, 2009.

[6] Sanghvi, J., Castellano, G., Leite, I., Pereira, A., McOwan, P.W., and Paiva, A.: Automatic Analysis of Affective Postures and Body Motion to Detect Engagement with a Game Companion, Proc. of ACM/IEEE International Conference on Human-Robot Interaction, Lausanne, Switzerland, pp.305-312, 2011.

[7] Tanaka, F., Cicourel, A., Movellan, J.R.: Socialization, between toddlers and robots at an early childhood education center, Proc. of the National Academy of Science of the USA, Vol.104, No.46, pp.17954-17958, 2007.

[8] Kozima, H., Michalowski, M.P., and Nakagawa, C.: Keepon: A Playful Robot for Research, Therapy, and Entertainment, International Journal of Social Robotics, Vol.1, No.1, pp.3-18, 2009.

[9］神田崇行, 佐藤瑠美, 才脇直樹, 石黒浩：対話型ロボット による小学校での長期相互作用の試み, ヒューマンインタ フェース学会論文誌, Vol.7, No.1, pp.27-38, 2005.

[10] Dautenhahn, K., Werry, I., Rae, J., Dickerson, P., and Stribling, P., Ogden, B.: Robotic Playmates: Analysing Interactive Competencies of Children with Autism Playing with a Mobile Robot, In: Dautenhahn, K., Bond,A., Canamero, L., Edmonds, B. (eds.): Socially Intelligent Agents - Creating Relationships with Computers and Robots, Kluwer Academic Publishers, pp.117-124, 2002.

[11] Howard, A.M., Park, H.W., and Kemp, C.C.: Extracting Play Primitives for a Robot Playmate by Sequencing LowLevel Motion Behaviors, Proc. of IEEE Int. Symp. on Robot and Human Interactive Communication, pp.360-365, 2008.

[12] Trevor, A.J.B., Park, H.W., Howard, A.M., and Kemp, C.C.: 
Playing with Toys: Towards Autonomous Robot Manipulation for Therapeutic Play, Proc. of ICRA, pp.2139-2145, 2009.

[13] Park, H.W. and Howard, A.M.: Understanding a Child's Play for Robot Interaction by Sequencing Play Primitives Using Hidden Markov Models, Proc. of ICRA, pp.170-177, 2010.

[14] Asoh, H., Motomura, Y., Asano, F., Hara, I., Hayamizu, S., Itou, K., Kurita, T., Matsui, T., Vlassis, N., Bunschoten, R., and Krose, B.: Jijo-2: an Office Robot That Communicates and Learns, IEEE Intelligent Systems, Vol.16 Issue 5, pp.46-55, 2001.

[15] Attamimi, M., Mizutani, A., Nakamura, T., Nagai, T., Funakoshi, K., and Nakano, M.: Real-Time 3D Visual Sensor for Robust Object Recognition, Proc. of IROS, pp.4560-4565, 2010.

[16] Attamimi, M., Mizutani, A., Nakamura, T., Sugiura, K., Nagai, T., Iwahashi, N., Okada, H., and Omori, T.: Learning Novel Objects Using Out-of-Vocabulary Word Segmentation and Object Extraction for Home Assistant Robots, Proc. of ICRA, pp.745-750, 2010.

[17] 小西嘉典, 木下航一, 勞世広, 川出雅人：リアルタイム笑 顔度推定, インタラクション, No.2008, Vol.4, pp.47-48, 2008.

[18］高木俊一郎, 坂本龍生, 園山繁樹, 門田光司, 谷川弘治, 伊東真理：TS 式幼児 - 児童性格診断検査 手引き, 金子 書房, 1997 .

[19］酒井恵子：子ども時代の遊びの好みと価值志向性, 日本教 育心理学会総会発表論文集, p.606, 2010.

[20] Feingold, A.: Gender Differences in Personality: A MetaAnalysis, Psychological Bulletin, Vol.116, No.3, pp.429-456, 1994.

[21] Hassett, J.M., Siebert, E.R., Wallen, K.: Sex differences in rhesus monkey toy preferences parallel those of children, Hormones and Behavior, Vol.54, Issue 3, pp.359-364, 2008.

[22］勝谷紀子：改訂版重要他者に対する再確認傾向尺度の信頼 性・妥当性の検討, パーソナリティ研究13（1）, pp.1120,2004

[23] Anthony D. Pellegrini: Domination and social integration in the behavior of kindergarten children in an experimental play situation, Early Childhood Research Quarterly, 7, pp.565-577, 1992.

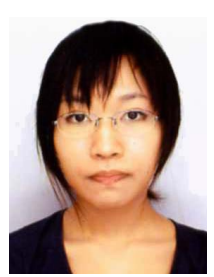

岩崎 安希子（非会員）

2012年 電気通信大学電子工学科卒業. 現在, 玉川大学大学院工学研究科電子情報工学専攻 修士課程在学中. 日本認知科学会学生会員.

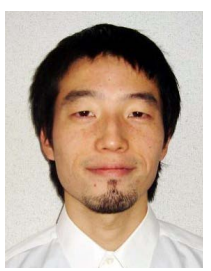

下斗米 貴之（正会員）

2003 年 北海道大学大学院工学研究科博士課 程後期修了．博士 (工学)。2004年 国立リ八 ビリテーションセンター研究所流動研究員. 2007 年 関西学院大学理工学部情報科学科契 約助手. 2010 年玉川大学脳科学研究所研究 員, 現在に至る. 感性工学・統計的学習論に関する研究に従事. 日本ロボット学会正会員, 感性工学会正会員, 神経回路学会会 員，電子情報通信学会正会員.

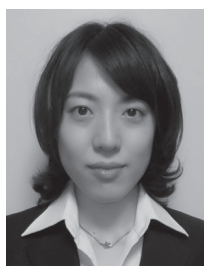

阿部 香澄 (非会員)

2009年 電気通信大学電気通信学部知能機械 工学科卒業. 2011 年 同大大学院電気通信学 研究科修士課程修了。現在, 同大大学院情報 理工学研究科博士課程在学中. 知能ロボット に関する研究に従事.

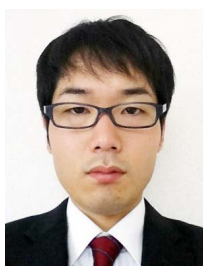

中村 友昭 (非会員)

2007 年 電気通信大学電気通信学部. 電子卒. 2009年 同大大学院電気通信学研究科修士課 程修了. 2011 年 同大大学院博士課程修了. 博士 (工学)。2011年 日本学術振興会特別研 究員 (PD). 知能ロボットに関する研究に従事.

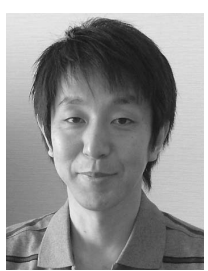

長井 隆行 (非会員)

1993年 慶應義塾大学理工学部電気工学科卒業. 1997年 同大大学院博士課程修了. 博士 (工学). 1998年 電気通信大学電子工学科助手. 2003年 カリフォルニア大学サンディエゴ校客員研究 員. 2004 年電気通信大学大学院電気通信学研 究科助教授. 現在同大大学院情報理工学研究科准教授. 2011 年よ り玉大学脳科学研究所特別研究員を兼務. 知能システム, 知能 ロボティクスに関する研究に従事. 日本ロボット学会, 情報処理 学会, 人工知能学会, 電子情報通信学会, IEEE 各会員.

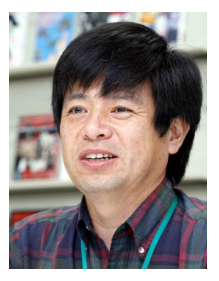

大森 隆司 (非会員)

1980 年 東京大学工学研究科修了, 1988年 東京農工大学工学部助教授, 1998年 教授, 2000 年 北海道大学大学院を経て, 2006 年よ り玉川大学教授, 現在にいたる。博士 (工学). 脳というシステムに知的な行動が生まれる情 報メカニズムに興味がある。電子情報通信学会, 日本認知科学 会, 日本神経回路学会などの会員. 